\title{
MADRASAH IN MUSLIM MINORITY: A STUDY ON ISLAMIC EDUCATION WEST PAPUA
}

\author{
Ismail Suardi Wekke \\ Islamic State College of Sorong (STAIN) \\ Jl. Klamono - Sorong, KM. 17, Klablim, Sorong 98417 Papua Barat \\ Email: iswekke@gmail.com, Phone. 0951-322-133
}

Papert Presented to The Second International Symposium

Empowering Madrasa in the Global Context

Horison Hotel Bekasi, 3 - 5 September, 2013

\begin{abstract}
Muslim minority exists in many part of Indonesia. Some areas that present muslim minority such as Menado in North Sulawesi, great area in Bali, Papua and West Papua at large. Those regions reflect that muslim live which is not similar with other muslim majority. Therefore, this research will explore madrasah in engaging empowering individual capacity in muslim minority. In short, this study will focus on madrasa role in enhancing muslim capacity in West Papua. This study conducted in West Papua Province. There are one city and twelve counties through the territory. Qualitative approach was utilized in multisite case study type. In-depth interview and non-participant observation were employed in collecting data. Field research was carried out on March to June 2013. Interview was performed with teacher, administrator, and educational bureaucracy. Furthermore, observation was presented in many activities, teaching and learning processes, and community development programs. Complementing data collection, focus group discussions were held in universities for series meeting. Another step to comply with triangulation is scholars consultation and peer-reviewed to ensure the research validity. This research shows that there are differentiation between muslim majority and minority in Indonesian society. Started from curriculum enhancement to program development formulate multicultural society. Self empowerment, entrepreneurship and skill improvement of movement were taken to ensure that madrasah establishments contribute to the society. Despite a controversial portrayal that media endorsed, madrasah and pesantren already demonstrate a great contribution during foundation of Indonesia in a nation. Madrasah also engage in civil society discourse, educational progress, promoting cultural awareness, and raising tolerance on religious variety. Through those activities, one of the major concerns is community development. This program was targeted to community educational awareness in madrasah surrounding area. They are running actions in term of basic need of those communities such as fishing, and farm treatment. In line up with those programs, it is to target the workforce problem. Muslim communities face high unskilled workers. Therefore, this program that ruined is one of the problem solving. On the other hand, religious understanding is also another concern. Students still need to attend classes in the morning to afternoon. They participate on those programs on evening and holidays. This progress is only to complement students' skill. However, tradition and culture are among problem in implementing those
\end{abstract}


objectives. Communication and discussion effort were constructed to considerate appreciation. Observing the progress of madrasah in muslim minority is appropriate. It shows that there is a significant contribution to enhance muslim current modernity in the region. Moreover, there is respond towards ideas of change in dealing with environment and progress. Finally, madrasah take a part not only in education activities but also society empowerment; culturally based activities are keys in empowering and development.

Keywords: muslim minority, madrasah, empowerment.

\section{INTRODUCTION}

Challenge after challenge is faced by students and the world of education. The dynamics of its environment is moving faster than ever. Every second, a better technological innovation is found. This forces every aspect of life to either follow its rhythm or be left behind. And as such, investors in education should continue to strive to prepare learners to adapt to this very dynamics. This demand calls for education that increases awareness in planning and instigating innovation. ${ }^{1}$ Thus, education is not merely a routine that loses meaning. Instead, education can become the catalyst of life. The third wave of education on the international scale presents a complex situation. Educational bodies not only function to educate but also to ensure the educational competency of its graduates. Education and muslim engagement in learning institutional is one of the concern through development of region. A study on this subject would enhance understanding part of development. As the pillar in the community, presences of pesantren enlarge teaching and learning opportunities beyond border.

One of the questions that receives the attention of every Muslim is identity especially those in a region where Muslims are the minority. One of the recent studies is muslim minority in Brastagi, North Sumatera. There are efforts to show existence in multicultural community. ${ }^{2}$ Although Indonesia is home to the largest Muslim community in ther world, in places like West Papua, Muslims are the minority. Furthermore, teenagers that tend to be easily influenced have begun to show hedonistic behavior. This shows that the comfort and joys of life have become number one priority. Susianto explains that this lifestyle is solely inclined to activities that focus on life's luxuries. ${ }^{3}$ Furtheromer, educational bodies play a vital role, where education is able to instill awareness among students that they can own their identity. At the same time, strive to develop harmony with other people of different beliefs.

Islamic education is a mainstream context of majority Muslims, where Islamic education has gained the attention of the community at large. However, there are still minority Muslims that develop education on a more local scale. Be it majority or minority, true Islam has always been the underlying struggle of Islamic education in its respective regions. As a part of education, curriculum is a pillar to strive the processes of teaching and

\footnotetext{
1 Lubis, Maimun Aqsha; Wekke, Ismail S; dan Syafar, Suhartini. 2009. Pelaksanaan Teknologi Komunikasi dan Maklumat dalam Pendidikan: Implementasi di Sekolah Bestari. Saemah Rahman, Mohd Izham Mohd Hamzah, and Auzar, Reformasi Pendidikan Serantau [275-282]. Bangi: Pusat Percetakan dan Penerbitan Universiti Kebangsaan Malaysia.

2 Syaukani, Imam. 2006. "Relativitas Posisi Minoritas Muslim di Tengah Mayoritas Kristen: Kasus di Kecamatan Berastagi”, Jurnal Penelitian dan Kajian Keagamaan Dialog, No. 62, Tahun XXIX, December: 55-69.

3 Susianto, H. 1993. "Studi Gaya Hidup Sebagai Upaya Mengenali Kebutuhan Anak Muda, Jurnal Psikologi dan Masyarakat, Vol. I, No. 1: 55-76.
} 
learning. Several definitive studies on Islamic education in term of its curriculum, one of which was conducted by Howell, concluded that sufism does not specifically employ a curriculum in its learning activities. ${ }^{4}$ Whereas a study by Andaya concluded that in a few studies of Asian education, female students are given a special position. ${ }^{5}$ Curriculum development has always considered the female student as part of its learners. Similar findings were met in a study by Smith-Hefner that explains female student as the main actor in education. The curriculum can also, though not limited to, be a means to develop a resolution for a conflict that occurs. ${ }^{6}$ Social woes can be overcome through careful and sufficient curriculum design. ${ }^{7}$ Drawn from those studies, it can be concluded that scholarly observations on Islamic education are still new and only focused on certain aspects. ${ }^{8} \mathrm{~A}$ more specific study on Muslims in minority areas has yet to be published. And so, it is the intention of this paper to depict the dynamics of Islamic education in a region where Muslims are the minority.

This article will explore the main focus is how madrasah engagement as an educational institution in muslim minority. There are many factors to conclude in term of madrasah in those areas. Other parts of Indonesia are muslim majority, while regional part of Papua, Bali North Sumatera and North Sulawesi are muslim minority. This research was conducted in West Papua. There are seven pesantren and madrasah were attended during data collection.

\section{ISLAMIC EDUCATION REFORM}

A study of pesantrenin the context of Islamic education reform has been conducted by Muljono Damopolii. ${ }^{9}$ The study specifically focused on Islamic education typology outside of Java. Damopolii found that IMMIM pesantren could not be represented using the same theorization for pesantren developed in Java. Damopolii's findings show that education reform on the scale for Sulawesi is appropriate with social development of its respective region. The demand for a body that manages mosques, and prepares its congregation calls for the establishment of an organization that strive to include all without excluding any of its ummah (community) no matter what their mazhab (sect) and understanding. Such an organization would be so advantageous that a pesantren can stand and exist in development without affiliating with other established societal organization.

Pesantren establishments started from a need of religious teaching institution. After all, it is expanded through many elements of life. The further developments extend to formulate formal school and its component, such as curriculum, teaching media and recent technologies. They are familiar with information and communication technology, millenniums discourse and world engagement. Those institutions are not only aware of religious issues an sich but also harmony, economics, etc.

\footnotetext{
${ }^{4}$ Howell, Julia Day. 2010. Indonesia's Salafist Sufis. Modern Asian Studies. Vol. 44, Number 05, September: 1029-1051.

5 Andaya, Barbara Watson. 2013. New Voices from Southeast Asian Women: A Review Essay. Journal of Southeast Asian Studies. Vol. 44, Number 01, February: 145-169.

${ }^{6}$ Smith-Hefner, Nancy J. 2008. Review of Robert Folger 'Images in Mind: Lovesickness, Spanish Sentimental Fiction and "Don Quijote." The Journal of Asian Studies. Vol. 67, Number 02, May: 747-749.

${ }^{7}$ Nir, Adam E; dan Eyal, Ori. 2003. School-based Management and the Role Conflict of the School Superintendent. Journal of Educational Administration. Vol. 41, Number 5: 547-564.

${ }^{8}$ Medoff, Marshall H. 2008. The Effect of Abortion Costs on Adoption in the USA. International Journal of Social Economics. Vol. 35, Number 3: 188-201.

9 Damopolii, Muljono. 2011. Pesantren Modern IMMIM Pencetak Muslim Modern, Jakarta: RajaGrafindo Persada.
} 
Additionally, categorization was implemented by Ahmad Tafsir for the region of East Indonesia, which could not record the existence of pesantren. ${ }^{10}$ If pesantren have existed for decades in Java that started from the kiyai (teacher) element, Islamic education in Sulawesi, Kalimantan, Maluku and Papua have started from the development of institutions. As presented by Dawan Rahardjo, since its beginning, institutions have been able to adapt to its surrounding community. ${ }^{11}$ For instance, it can always adapt to the needs of locals. In a different development, pesantren have been able to conduct reform suited for its locality and so, a pattern employed for a given place cannot be guaranteed to suit another locality. Pesantren's independence factor is important in answering to social changes, whereby it is aware of the ever changing social conditions.

Even in a study by Steenbrink, which was conducted long before studies by Damopolii, Rahardjo and Tafsir, show that there are three categories for educational institutions that have become the answer to the needs of Muslims. In this instance, pesantren, madrasah and schools are maintained and operated by the community. Every community adopts the characterisics and conditions available. In Ponogoro, a Pesantren Darussalam was built to serve the community's needs to learn Islam. Therefore, to support the learning, it is a need to master Arabic and English. Whereas in Minangkabau, an educational institution called Thawalib was developed. In Medan, the community developed Jamiyatul Walisyah and in Java, Muhammadiyah and Nahdhatul Ulama. On their own, these organizations and bodies fulfill the educational needs on the local scale, which not only covers elementary education but beyond, to higher education. ${ }^{12}$ The dynamics of these institutions show that there is indeed a reform effort of education that occurs simultaneously with the development of Muslim community. This presents innovation and reform of education for the sake of immediate localities. Even if it ultimately has a broader impact, this is only because it has garnered the attention of other localities. Though from early development it was not intended to attract other regions, continuous success and innovation have proven the solidarity of such institutions.

In a recent development, Islamic education does not only ruin on religious issues. Contemporary issues such as the culture of minority, ${ }^{13}$ curriculum and entrepreneurship development, ${ }^{14}$ community empowerment, ${ }^{15}$ humanism, ${ }^{16}$ have taken centre stage in Islamic education. The diversity of issues undertaken by Islamic education institutions show apparent variety in focus, as well as dynamics in observing development patterns that is consistent with the needs of learners. This proves that the ability of Islamic education to adapt to global development is a unique factor in itself. And so, it is though these educational institutions that the spirit of Islam can push Muslims to strive for appropriate

\footnotetext{
${ }^{10}$ Tafsir, Ahmad. 2000. Ilmu Pendidikan dalam Perspektif Islam, Third Edition, Bandung: PT. Remaja Rosdakarya.

${ }^{11}$ Rahardjo, M. Dawam. 1995. "Dunia Pesantren dalam Peta Pembaharuan”, Pesantren dan Pembaharuan, Fifth Edition, Jakarta: LP3ES.

${ }^{12}$ Steenbrink, Karel A. 1994. Pesantren Madrasah Sekolah, second edition, Jakarta: LP3ES

13 Makbuloh, Deden. 2012. "Kultur Minoritas dalam Perspektif Pendidikan Islam", Jurnal Studi Keislaman Analisis, Volume XII, Number 1, June: 137-160.

14 Wekke, Ismail Suardi. 2012. Pesantren dan Pengembangan Kurikulum Kewirausahaan: Kajian Pesantren Roudahtul Khuffadz Sorong Papua Barat. Jurnal Penelitian Sosial Keagamaan Inferensi. Vol. 6, Number 2, December: 205-226.

${ }^{15}$ Wekke, Ismail Suardi. 2011. Pendidikan Islam dan Pemberdayaan Masyarakat (Tinjauan Pendidikan Vokasional Pesantren Roudhatul Khuffadz, Sorong). Jurnal Kajian Interdisipliner Hermenia. Vol. 10, Number 1, December: 23-53.

${ }^{16}$ Abdurrahmansyah. 2010. "Kontribusi Kurikulum Humanisme bagi Implementasi Pembelajaran Nilai di Indonesia”, Jurnal Kajian Pendidikan Islam at-Tarbawi, Volume 9, Number 2, November: 131-150.
} 
aspirations that are based on the path of Islam. In this sense, attention is always given to observe the relationship between god and human capacity development.

Those studies reflect a long history of pesantren establishment. Through the program and participation in education, madrasah and pesantren tried to accelerate enhancement in their institution. Adaptation, organization, and society recognition are keys to activate reformation in education. The evolution of pesantren rely is the process to cover multidimensional activities on the basis of society.

\section{EDUCATION CURRICULUM AND DYNAMIC ENVIRONMENT}

The early Islamic education dynamics solely focused on a place to learn religion. All sorts of terms were used to describe pesantren such as in Minangkabau, it is called surau, in Aceh, it is known as dayah, and in Sunda, it is called pondok. All of these depict pesantren as an institution that stems from the community. Socialization within rural communities then developed alongside with the development of pesantren. Moreover, the modern world demands have urged pesantren to integrate the needs of local community with religious education. In addition to its initial purpose of relaying religious education, current social situation demands it to adapt to current technologies. In addititon, the pesantren is truly an adaptive institution that can handle change. Furthermore, the patterns of these institutions developed further in response to harmonizing the community. However, the fulfillment of these external needs have not overcome the preceding classical education.

The contextual dynamics of environment leave an impact for the need to develop the curriculum. In a unit of education such as in Bali, education is not only a formal means for educational transformation. ${ }^{17}$ More than that, it is a means to tighten the ties of the community together. Education is not used to instill religious fanaticism that may trigger disputes. Education is thus, earthed and not separated from its environment. Similarly, religion should be the liberator of life and not just stuck in a romanticized formal situation. With that, the demands of the environment encourage curriculum development based on their respective needs and at the same time, not withholding from regional and national demands. Therefore, learners can belong not only to the local community but also the citizens of a region and nation.

This is the vision that is being endlessly developed and drafted within the world of education. ${ }^{18}$ The vision was developed early on stemming from a practical interest of its environment. By relying solely on memorization, comprehension suffers. In favor of this, Wertheimer stated that there is a need to have a vision for learning. At the very moment a student is confronted with a problem, experience and vision is needed to solve the problem. Should they focus only on experience, they would need a very long time to experience it themselves. But with a vision, experience can occur as a result of the experience of others. This means that there is a restructuring of a new social situation supported by available vision. When experience, vision and restructure are present in a related cycle, problem solving can truly be reached.

Equipped with understanding and logic, a student can move toward reaching a conclusion. Mastering an environment will encourage toward learning activities that are environmental needs and demand oriented. A study has shown that even in learning chemistry, the principles and practical experiments conducted need to always be aware of

\footnotetext{
17 Jannah, Siti Raudhatul. 2012. Kegalauan Identitas: Dilema Hubungan Muslimin dan Hindu di Bali. Jurnal Studi Keislaman Ulumuna. Vol. 16, Number 2, December: 443-464.

${ }^{18}$ Wertheimer, M. 1945. Productive Thinking. New York: Harper \& Row.
} 
the people outside of the laboratory. ${ }^{19}$ The approach stems from two factors, namely theory and practical, to instigate the process of learning that is relevant to the case study. This means that learning cannot be isolated from external parties. Even if there isn't any connection between the two, there will always be one or more external parties to be considered in enriching the learning process.

The connection between environment and its community members is important because the environment will be the location for the community's actualization. Resynchronization between the community and environment will cause isolation. In the process on internalization, an evaluation followed by saving and recalling an experience is a cognitive process that does not occur in an instant. Instead, it requires a continuous process that involves four educational framework beginning from initial capacity, purpose of education, followed by practice method and finally, evaluation procedures. ${ }^{20}$ All of this is comprised in a student's experience cycle, which is hoped to develop their skills.

Socio cultural approach sees learning as a partisan. Thus, in a community, habit and practice becomes the tool for measurement. Not only to symbolize religion as a cultural identity but even more, to encourage comprehensive understanding of the religion and subsequently, religion as a construction of everyday routine. Regarding identity, it is a viewpoint in the social context, making it the general strategy in learning to relate existing context and culture. At the same time, the requirement and variation needed for every individual to become a better learner should be observed. Generally, current curriculum as set by the national system will not represent the environment spirit of every region or province. In order to have a curriculum that fits with every region, identification from the system to implementation in class is required. The materials presented should undergo a communication process with local environment. Gerrard, Albright, Clarke et al. explained two aspects in the reform of curriculum. ${ }^{21}$ The aspect of region and curriculum requirement should be arranged in such a way to create implementation in the classrooms. This means that education, without considering the aspiration of surrounding environment, will only serve as a bureaucratic interest.

Curriculum was expanded from community observation and awareness on needs and recent situations. It shows that group conditions as the element of information to formulate teaching implementation. Religious teaching conducted through Islamic traditional teaching books. Pesantren maintain the traditional system of learning. On the other hand, they try to achieve another objective. It is a social function to adapt and manage community expectations. Pesantren classify their activities to present founding of teaching and learning both knowledge and subject needs. These findings reflect pesantren to serve local agenda. They provide social service, network adjustment and organizational strength. They have local volunteers throughout village which perceived positively and supported.

During learning process, it implies cooperation to achieve common goals, both society and pesantren itself. They implement a learning model in which student study and work together in the field with structure group that is heterogeneous. Furthermore, great objective achievement depends on that collaboration. It basically contains how pesantren work or help the others in regular programs. Working and studying together among fellows

\footnotetext{
${ }^{19}$ Dicks, A. P. dan Batey, R. A. 2013. The Organic Curriculum: Development of an Undergraduate Catalytic Chemistry Course. Journal of Chemical Education. Vol. 90, Number 4, April: 519-520.

${ }^{20}$ Holden, Rick dan Griggs, Vivienne. 2010. Innovative Practice in the Teaching and Learning of Human Resource Development. Journal of European Industrial Training. Vol. 34 Number 8/9:705-709.

${ }^{21}$ Gerrard, J; Albright, J; dan Clarke, D. J. dkk, 2013. Researching the Creation of a National Curriculum from Systems to Classrooms. Australian Journal of Education. Vol. 57, Number 1, April: 60-73.
} 
and citizens going to the motivation, productivity and acquisition of learning. It is more that a study group. There is a presence of emotion as the structure. Cooperation opens occurrences and relationship of independence. Next, both results are encouraging and allowing alternative solutions to learn.

\section{PREVIOUS STUDY}

Access to education and the long distance to adequate infrastructure are two features of a madrasah in Jayapura. Such was observed by Nurudin. ${ }^{22}$ This means that there is other different point of views regarding madrasah in other regions and the madrasah in Papua. One of the issues is the need to form a Muslim identity in the education process. Regarding the relationship between different ethnics, it is possible that ethnic awareness and the desire to show own identity will surface. ${ }^{23}$ There is a potential for identity reinforcement to show its substance in religion and regionalism. Within certain boundaries, rises the expression to display existence. Even so, it is not as commonplace as it seems according to Muridan S. Widjojo. ${ }^{24}$ The fact of ethnic and ethnicity is very dynamic. So much so that even the meaning of ethnicity varies, depending on the context and how the ethnicity issue is played out.

Skill training for madrasah students has also come into focus among observers. Amiruddin presented that there is an integration of curriculum with the needs of female students. The adaption was later found to include local elements. ${ }^{25}$ Just as the society construct places women as the caretaker in the kitchen, and so does the pesantren that specializes in schooling female students, whereby cooking and sewing are included in the list of subjects. In the meantime, Supardi and M. Natsir observed the need for accreditation. ${ }^{26}$ Apart from the need to develop the curriculum, the madrasah also needed recognition from external parties in the form of accreditation from the Madrasah Accreditation Council. The study also showed that there were various requirements that needed to be met by every madrasah in the process for accreditation. Improvement and development of these institutions are required to gain accreditation, whereby the study found only $30 \%$ of the madrasah involved were able to fulfill the accreditation criteria. Both of these findings point to the fact that the madrasah are actively striving to obtain external recognition in order to reinforce the institution's operations. Obviously, the expected hope is to enrich the capacity of its students.

Other than the issue of pesantren in term of the previously mentioned accreditation, infrastructure and ethnicity, pesantren has also showed strength in cultivating multiculturalism. The transformation of pesantren into modern institutions sees the inclusion of democracy elements, cultural diversity and tolerance among students. Furthermore, pesantren have also become the institution that initiates peace by forging reconciliation. ${ }^{27}$ Similarly in Aceh, after the tsunami disaster, the Islamic education

\footnotetext{
${ }^{22}$ Nurudin, "Mendesain Madrasah di Tanah Jayapura: Sebuah Kasus Kota Jayapura”, Jurnal Penelitian Pendidikan Agama dan Keagamaan Edukasi, Vol. 9, No. 3, September - December 2011, 4644-4671.

${ }^{23}$ Geertz, Clifford. 1973. The Interpretation of Cultures, New York: Basic Books.

24 Widjojo, Muridan S. 2007. "Nasionalisme dan Etnisitas", Firman Noor (ed), Nasionalisme, Demokratisasi dan Identitas Primordialisme, Jakarta: Puslit Politik LIPI.

25 Amiruddin. 2010. Muatan Lokal dan Tantangan Dunia Kerja di Madrasah Aliyah Pondok Pesantren DD Lil Banat Kota Parepare Provinsi Sulawesi Selatan, Jurnal Penelitian Agama dan Sosial Budaya, Vol. 16, No. 26, July - December: 161-170.

26 Supardi dan Natsir, M. 2006. Analisis Kebutuhan Pengembangan Madrasah di Kota Mataram Menghadapi Akreditasi Madrasah, Jurnal Penelitian Keislaman, Vol. 3, No. 1, December: 79-98.

${ }^{27}$ Hamdi, S. dan Smith, B. J. 2012. "Sisters, Militias and Islam in Conflict: Qusetioning 'reconciliation' in Nahdlatul Wathan, Lombok, Indonesia”, Contemporary Islam, Volume 6, Number 1, April: 29-43.
} 
institutions based on Aceh's local culture known as dayah played the important role of handling children who were left orphans. Such is the attention given to surrounding issues. The pesantren's environment can also be made an example of environmental conservation. ${ }^{28}$ The variety of activities focused by students proves that they are active, not passive and only care for religious education. On the contrary, there are apt to become the social strength of their respective community.

Even more so when in the main environment, focus of the pesantren is as the Islamic education institution. The development of morals is the answer to the need for character education in context of Indonesia's national education. ${ }^{29}$ The establishment of pesantren presents the "spirit of education" in the education system. ${ }^{30}$ Even before Indonesia's education was developed formally, the pesantren were the pioneering effort in developing education. Even with civil society of today, they cannot escape the important role played by the pesantren community. ${ }^{31}$ Finally, pesantren also contributes to the development of the community's economy. ${ }^{32}$ Descriptions and explanations previously mentioned above show that the pesantren is a locomotive of change. The development of institution ultimately leaves a multidimensional impact on the surrounding community and environment. This in turn will eventually impact, not only the local environment, but also at the national scale of things. Such position of the pesantren will then become its own phenomenon to be studied so that it can be said as a main component for harmony of the diverse Muslims in Indonesia.

\section{RESEARCH METHOD}

This study was conducted using a qualitative approach in the form of case study. A qualitative approach was chosen for the suitability between the problem and object of study. And so, the approach used can comprehensively answer the issue at hand. As a case study, the study investigated a program covered in curriculum development. Since there were time and activity limits, procedures implemented for the case study will provide sufficient information for the results of study. Specifically, three steps were undertaken starting from data collection, data presentation by data average reduction and interpretation to form conclusion, and overall data presentation. Creswell called this strategy in qualitative approach. ${ }^{33}$ Implementing a case study strategy, specifically on the phenomenon of curriculum development at the Pesantren Nurul Yaqin, can lead to a more just investigation. The specific limits to the program and activities in curriculum development will provide the scope, ultimately the study parameters in details. Putra also commented that a case study is a strategy to collect and analyse any given program. ${ }^{34}$ An

28 Mangunjaya, F. Majeri. dan McKav, J. Elizabeth. 2012. "Reviving an Islamic Approach for Enviromental Conservation in Indonesia", Worldviews: Environment, Culture, Religion, Volume 16, Number 3: 286-305.

${ }^{29}$ Izfanna, D. dan Hisyam, N. A. 2012. "A Comprehensive Approach in Developing Akhlaq: A Case Study on the Implementation of Character Education at Pondok Pesantren Darunnajah", Multicultural Education and Technology Journal, Volume 6, Number 2, June: 77-86.

${ }^{30}$ Nilan, P. 2009. "The 'spirit of education' in Indonesian Pesantren", British Journal of Sociology of Education, Volume 30, Number 2, March: 219-232.

${ }^{31}$ Sirry, M. 2010. "The Public Expression of Traditional Islam: The Pesantren and Civil Society in PostSuharto Indonesia”, Muslim World, Volume 100, Number 1, Januari: 60-77.

${ }^{32}$ Permani, R. 2011. "The Presence of Religious Organisations, Religious Attendance and Eranings: Evidence from Indonesia”, Journal of Socio-Economics, Volume 40, Number 3, May: 247-258.

${ }^{33}$ Creswell, John W. 2010. Educational Research: Planning, Conducting, and Evaluating Quantitative and Qualitative Research, Boston: Pearson.

${ }^{34}$ Putra, Nusa. 2012. Metode Penelitian Kualitatif Pendidikan. Jakarta: RajaGrafindo Persada. 
analysis can be made of a condition, and so the development and activities can be observed, as well as the factor that supports the activities.

Data collection was implemented using in-depth interviews and non-participant observations. Interviews were conducted with teachers involved in curriculum development, administration staff and head of the pesantren. Data collection was carried out for three months. For the interviews, a guideline for interview was used, while during observations, a guide sheet for observation was employed. Both instruments were useful in supporting the objective of data collection from the subjective aspect of the observer. During analysis, data were gathered in phases to verify with other sources. Through such data triangulation process, even the data collected from beginning is valid data. Additionally, in order to ensure the validity of the data, the data collection period was extended to five months, whereby data were check for correctness and validity through focus group discussion. Also conducted was a check between colleagues and consultation with expert scholars to ensure that the data collected have undergone thorough multistage inspection.

Field research was conducted in Pesantren Roudlotul Khuffadz, Aimas; Pesantren Mainhajut Talibin, Aimas; Pesantren Nurul Yaqin, Mariat; Pesantren Darul Istiqamah, SP III; Madrasah Emeyodere, Victory Pantai; Madrasah Ibtidaiyah Yapis al-Jihad, Klademak; and Pesantren Hidayatullah, SP III. Those seven institutions represented school and learning society that drawn from criteria existed.

In order to avoid data bias, observations were made in a non-participatory manner. The researcher took away himself a distance from the subject of observation. The observer's presence during data collection was so that it did not become a factor that interrupted the field of observation. This was done to ensure a naturalistic environment. Before reaching the location to be observed, early preparation measures made were to gather a plan for data collection and analysis. In the views of Baxter and Chua, this needed to be done by setting the objective first before going to the field and starting the observation. ${ }^{35}$ Thus, with the devised plan, it is used as a guide for analysis to answer the study problem at hand.

\section{REALITY OF EDUCATION FOR MUSLIM MINORITY}

Muslims in West Papua live in a multiethnic community and thus is confronted with challenges but at the same time, opportunities. This is the dynamic of the education institution there. The Pesantren Nurul Yaqin, in Kabupaten Sorong, with the support they receive, strives to serve the Muslims with education. Uniquely, the education institution was built by the local everyday bureaucrat Muslims. Aware of the lack of an institution that provides knowledge to the Muslim youths, the pesantren was developed. Seeing that they live among those of different beliefs, the Muslims are susceptible to stray. It is where an Islamic identity has not developed in various life interactions with others. Looking past the process of institution, daily operations of the pesantren are managed by the teachers and heads, who are mostly newcomers to the region. With that said however, some of the heads are local Papua Muslims.

The strategic positions of the pesantren and madrasah in Papua support the existence of Papua Muslims. Apart from other religions, Papua has welcomed Islam rather early. There were several tribes in 1700's that embraced and inherited Islam, namely the Kokoda, Inawatan, Arguni and Arandai tribes. Because there was no Islamic education institution at the time, there have been cases where some of them received education at

\footnotetext{
${ }^{35}$ Baxter, Jane dan Chua, Wai Fong. 2008. The field researcher as author-writer. Qualitative Research in Accounting \& Management. Vol. 5, Number 2: 101-121.
} 
another religion's educational institution. This inadvertently involved them in religiousbased traditions that were of the institution. For that purpose, the pesantren and madrasah are important infrastructures in instigating an Islamic identity. With everyday interaction among the multiethnic community, sometimes a Muslim may be caught unaware of how to behave accordingly to his own religion. Heterogeneity and being multiethnic may at times result in a habit or behavior that is the opposite of Islamic teachings. And so, through education, awareness to always stay true to one's religion can be cultivated, including interaction with believers of other faiths.

Teachers and instructor use a sort of historical record of every student to monitor directly their progress in learning. The record can also be used by any of the teachers on duty. This also eliminates the dependency on just one instructor and at the same time, helps develop diversity among both male and female students. The records are a form of effort to develop a reality that can later be evaluated. At the same time, a positive and negative attitude cannot be formed one-sidedly. It can instead be used to crush the negative attitude. These records will help overcome any obstacle that may come in the learning process. It can also be used to understand the complexity of students' development as teenagers. Needed is the reorientation of experience and thought, including the communication aspects. When innate culture is a part of someone, it will become their expression, view and action.

Society expect from the learning institutional to expand students' knowledge to skill. There is a need to master many vocational complement. This condition rises from neighborhood and environment. Therefore, pesantren and madrasah implement various programs to charter those needs. School curriculum is complemented with practical time allocation. In line to this practice, the resources are available from their environment. In education context, teachers should go to beyond classroom activities. It is not focused in classroom only, but also expands to after classroom program. Teachers obtain information and common difficulties from previous year. Then, he or she tried to enhance teaching and learning material base on social condition. In the context of classroom, teacher only focus on basic recognition. In the field of laboratories, teachers communicate skills and psychomotor area through practice.

Indeed, pesantren regarded as an essential part of learning. In order to understand the process of empowering in pesantren, the process of learning constructs a system. First, teachers' competencies are smart enough to charter the goal of learner. Second, they provide a spirit to learn. There is a system that implemented continuously. Consequently, students remain to learn and progress toward the goal. Third, there is may be the most important, students are indispensable to the learner their self. Because it can regard the making of errors as a device the learner uses in order to learn. Finally, students perform their competence. It is a result of facing problems that encourage learners to perform success in multidimensional aspect of life.

According to the basic principles en education, pesantren already present high condition to ensure quality. On the early stage they determine curriculum to envoy students' ability. Through contextual teaching and learning, classroom act to improve and explore students' personal result. Context of learning in pesantren appear to be able to learn religious competency quite easily and to reproduce muslim. The main conclusion is pesantren dose not avoid to construct study element. Eventhough, it is religious material learning.

Most students of senior high school already comprehend on understanding and skill which field they choose. In practicing the daily activities about study and work, students usually collaborate in some aspects. A problem which commonly faced by students is 
discussed in small group. Students who want to consult supervisor can proceed to appropriate schedule. It is also aimed to avoid continuous problem. They also have a space to conduct practices before going to the field. The simulations improve of managing terrace as a result, mastery differentiating process and taking steps to enhance students' competencies in solving problem.

There is abundant of motivation. When teachers and instructor already explained the learning material is good enough received by students. Another program is arranged to enhance and stimulate students' mastery. They create process of learning seriously. Students focus when teacher explained at classroom and give attention to teachers. Before coming to the class, students read learning material that explained a week before. It shows there is pre-activity before performance. After class, training, discussion, and simulation supplement the learning.

Students write their performance every day. From the journal, they learn to identify and describe their learning structure. It is shared to other groups. Somehow, when they find difficulties in understanding, collaboration with instructor conducted to present discussion. Well-trained supervisor involved to provide feedback. This teaching-learning strategy simplifies a systematic progress. Employing this discovery learning stimulate skill acquisition. Problem identification was classified to figure out the recent condition. Detection, classification, and action were taken to solve any problem.

\section{LEARNING AND CURRICULUM DEVELOPMENT}

Since the very beginning, the philosophy practiced for Islamic education is that it does not recognize the dichotomy of knowledge to the point that the knowledge learnt are all merely Islamic nuances. The principle of knowledge and activities in learning lies in the fact that Islam provides the basis to develop said knowledge. It is not based or adopts knowledge from Europe or North America. Tauheed is the main foundation that is central to the entire principle being practiced. Religion equals knowledge but religion also drives knowledge. This principle is also supported by tauheed, making the knowledge learnt at the pesantren impartial knowledge that is integrated with religion. Therefore, knowledge engagement is one of the most holy activities to serve human beings.

As a response to a multiethnic community, which is not only from an external context and more on the internal condition of the Muslims, the purpose of learning as identified is how students can respond to changes in the condition when they are outside of the pesantren. The community as a system is seen as the purpose and target. Changes within the environment occur every second, and so even from the start. Students are geared toward being a member of multiethnic society that continues to change and grow. In order to do, students are equipped and supported with various skills so that they are able to endure any and every consequence of change within the community and environment. Hence, Islam is the solution - complete for every stage of change. The teaching of tauheed and Islam is the main material. Comprehension of the Quran and Hadith is the initial foundation. For that, the earliest skill trained is reading the Quran. The spirit encourages educational practiced and extend the community to improve learning institute.

Learning is geared in the form of managing the learning environment to assist students can achieve set learning goals. Two things that are always emphasized for making the learning process meaningful are change in behavior and result of interaction within the pondok environment. Not limited between students and teachers, this includes among students, even with other students from different institutions but within the same region. There is an apparent total learning process in a social system jointly developed. When learning, a student's personality is the reflection related to his or her learning materials. 
Whereas the teacher, while teaching, show a personality that is suitable for their professional conduct. At the same time, there is responsibility and duty. The relationship between student and teacher is formed through instructional learning.

In pesantren education process, the learning is supplemented with deeper understanding of materials in the form of classical book studies. For that objective, the teaching of Arabic language is intensified and emphasized from the very beginning. The lesson period for Arabic may reach five hours a day and is not included in the madrasah's curriculum in the morning. Arabic enrichment also occurs at the students' dormitory. In order to develop a good grasp on a language, a well-planned tutorial before and after formal education at the madrasah is prepared. This also includes studies of books at the mosque. Formal education is deemed insufficient for the students. And so, additional activities after formal education is hoped to fill in the blanks. Through this process, students can be better-rounded in term of religion. Pesantren is merely a place of training. The real results of education at the pesantren can only be seen after the students go out into the world outside of the region.

To complete further supplement students' skills in reading the classical books, the formal education includes lessons in literature that originated from the classical jurisprudence (fiqh) books. Whereas the practical employs the Gontor education system with modifications made according to students' abilities. Input from students originating from West Papua such as Bintuni and Raja Ampat have shown that their initial ability was very heterogenous. This in itself is an obstacle and can be overcome by matriculation during the early months of the academic year. Other programs are also conducted for the purpose of enriching the learning materials in the evening especially for subject taught at the pondok. Takhassus (special) classes arranged are also held with the help of senior students for those who have yet to master it.

In the meantime, evaluation used was not only based on cognitive skills. More than that, religious practice in daily life also becomes the main focus. In any subject, there are several forms of evaluation adapted to suit the characteristic of the lesson's materials. All sort of evaluation methods are used in order to train the students with skills that will not make evaluation their goal. Evaluation is merely a mean to improve the student's' skill. The flexibility of evaluation is emphasized to produce graduates that truly understand completely the knowledge they have learnt. Continuity of the knowledge and skill gained by the students is hoped for because as it is religion-based, it is not limited to the classroom but beyond, even until the end of life.

The purpose of evaluation and measuring of competency is part and parcel of curriculum right from the start. The intended purpose for evaluation is clear. Evaluation used have the following characteristics (a) improvement of learning process, (b) administration students' ability achievement, (c) identify problems faced by students during learning, (d) student placement is suitable with their abilities. Competency achievement is also measured across the different subjects. Further measurement is on graduates' competency that is monitored since they first started in class one to class six, with advancement to madrasah aliyah. With a systematic framework of learning and predetermined target, the students have to reflect their achieved ability in the form of basic values in life at the pesantren. It is hope that their achieved skills are not only used at the pesantren but also when they are no longer in the pesantren environment. The main goal, when students are graduated from pesantren, they will extend their religious knowledge to their society in the form of teaching.

In the learning process, the teachers and heads at the pondok are always open for thought contributions on the development and enhancement of the curriculum. For that, the 
school regularly invites education experts and communicates with heads of otherpesantrens that have been around longer. Many activities were implemented to gain voice and participation from the society and governmental institutions. This means that the process for innovation never stops - it is always revolving and adapting to suit the dynamics of the local society. Even though stages of curriculum development are done regularly the opportunity to contribute new ideas is always open. Communications with stakeholders are conducted in stages through various communication channels all year round. While not easy, adaptation and benchmarking are implemented to resolve problems faced. Education facilities are also completed, specifically those related to learning mediums. For that purpose, in order to support the advances in innovation, the school is open to discuss new experiences or new definitive study findings. This is done in a plan to develop understanding so that the values being cultivated correspond to being open for new ideas, even from external parties. Another program is a visiting scholar invited to teach and stimulate new insight.

The madrasah's curriculum was developed as a mean to cultivate harmony and avoid conflict. Religion has always been the means for public life. Religion, through education, can also then be an inherent part of the collective awareness. So much so that even religious rituals are no longer unfamiliar from the dynamic environment. Instead, religion should be internalized in order to guarantee spiritual wholeness, even outside of the religious practice realm. The truth of religion is not limited to the space where it is practiced such as the mosque but it should go beyond the terminology of truth. With continuous change that occurs with time, this process also responds to the preparedness to respond to actual reality.

There are swift realities that affect the path to the future. Today's ideas are always used for the interest of the future. And for that, timidity or reservation is not the basis of education at the Pesantren Nurul Yaqin. The relationship between pesantren and the community mutually exists; pesantren as the source of education. Whereas the community becomes the partner in supporting and facilitating students in gaining valuable experiences to form their learning processes. This network of action and participation will allow a student to reconstruct the learning experience they gain from the community. This demand presents a meaningful and authentic opportunity. At some level, this will ultimately make students responsible for the choices they make. Mistakes, failures and absent-mindedness can also be a medium to learn. Not in the negative sense but they provide the chance for students to directly learn from it.

Here, a contextual understanding is used to provide a solid picture. All this while, the education process only relied on partial understanding. For that, where a pesantren is located among Muslim minority society, the social phenomenon is to have the chance to understand historic records. And so, the pesantren has developed a curriculum that answers the issues surrounding the life of Muslims. Its orientation is in the current context and accepts the reality of a plural and multiethnic community. Being among believers of other faiths propose a challenge in developing a curriculum suitable for the daily learning materials at the school.

\section{CONSTRUCTION OF MADRASAH EMPOWERING}

In term of empowering, madrasah and pesantren in muslim minority shows a great part of advancement. There are two kinds of main expansion. First, individual transformation in capacity building is in religious formal educational. A need of teaching and learning is implemented through classes and practical training. Those activities enhance an individual to practice Islamic request. Second, community development is a 
part of society concern. People to people contact are a key to organize participation in larger community. This is not only for muslim group but also available for any ethnic and religion attachment. Pesantren tried to speed up many programs and invite as many as people to come and join the program.

This idea is a part to facilitate social justice in the presence of Islamic education. It does not mean that Islamic only come and preserve muslims require. It is necessary also to affect social zone. Pesantren applied a wide range of initiative. In this agendas, organization works through exploratory stage to transmit positive personal and social behavior about diversity awareness. Society background and multicultural in religious variety can be seen as daily life phenomenon. Pesantren cannot deny this occurrence. Furthermore, the movement is trying to charter this fact in supporting dynamic of social and cultural context. Cultural pluralism is practices, therefore pesantren prepare student living in the society that regard variety of many aspect conditions.

A centre of learning and teaching already play important role. On the other hand, it is not enough to interact in exclusive situations. Existence of pesantren is needed to formulate Islamic value system as a support of human, without regarding their religious affiliation. When effective teaching and learning are reached, the goal of service is exactly the same, namely to develop the ability of students to interact with others. It is not necessary if an educational organization only focus to relate on own culture and religion. Every time, world feature shapes a unique identity. On this situation, pesantren and madrasah in muslim minority preserve characteristics in keeping intellectual tradition. They have a significant contribution on contemporary integration. Education systems for internal aspect utilize to maintain process of ibadah (workship). In addition to society, resident of community interact with pesantren to maximize human potential. Accessibility to others religious believer is adequately to attempt cross cultural settings.

Another important concern is inspiring student to serve human beings. A major approach of pesantren existence in muslim minority to facilitate basic literacy skill of ethnically different people. It is importance evolves of school failure in many suburbs area. The relationship among relevance instructional efforts and material achievement build problem solving. Pesantren provides dual responsibility to engage and understand the people and happening around. Education is also responsible to work toward eliminating prejudices and identity discrimination. Progressively involvements continue to maintenance social justice and equity. At last, pesantren and madrasah provide directions and enterprise in principles of pedagogy and conceptions of educational equity.

\section{THEORETICAL IMPLICATION}

This study once again showed that the existence of a pesantren is as the pioneer in social change. As described by Ziemek, from the beginning the pesantren showes involvement in problems that occur within society. ${ }^{36}$ It is not uncommon that such involvement makes the pesantren a centre for problem solving activities. While the main scope of activities at the pesantren is religious education, social interaction is not excluded from the scope. As an education structure, accompanied by the charismatic leadership of the kiyai, the pesantren is strategically places as an institution of the community. Although the pesantren institution development is usually autonomous, it is an open institution. Ziemek also found how pesantren have undergone a process of modernization through a precursor that stems from the pesantren itself. After that, with modernization, it propels itself to better contribute for its environment. Ziemek findings as early stage in studying of

\footnotetext{
${ }^{36}$ Ziemek, Manfred. 1986. Pesantren Dalam Perubahan Sosial. Jakarta: P3M.
} 
pesantren stimulate further research, include this study. His explanations begin as a pioneer of pesantren studies. It took to further discussion how pesantren as an institution to formulate society empowerment.

Corresponding to the national synergistic dynamics, the pesantren, according to Mastuhu, is a national cultural treasure. ${ }^{37}$ Two matters were proposed by Mastuhu as the pesantren's main social capital, namely Islamic identity and concern for the community. Before Indonesia founded as a nation, pesantren was already present. Then, when Indonesia struggled to stand on its own, pesantren also participated in the movement. When independence was proclaimed, the pesantren was ready to consolidate and fully participate in being a subsystem of the national education. Now, pesantren continues to fortify itself to become a multidimensional institution. Not limited to education but beyond the scope of education. They always are being an actor in every change within their respective environment. This is possible because pesantren is in the community. Its birth, nurtured by the community will always be defended by its society for it has always fulfilled the local needs.

The study also shows that the management of education at the pesantren has always been the main focus. Curriculum development has been informal. Efforts to develop a curriculum have always reflected the demands of the community, which is done constantly. The condition of being in a multiethnic community, the Pesantren Nurul Yaqin has adapted the spirit and excelled in formal education. As with other pesantren in areas where Muslims are the minority, they have to be innovative in entrepreneurship. ${ }^{38}$ Similar is the purpose of empowering the community. The pesantren in Kabupaten Sorong has made this their mission. ${ }^{39}$ Being the minority group, challenges of supporting the economic capacity of Muslims in the area is the responsibility and mission of education. Without its role and educational transformation that would lead to community empowerment, Muslims are merely a part of pesantren.

Islamic education in West Papua has always provided support to its community, as the main character ever since pesantren was established. The practice of pesantren, as stated by Lukens-Bull, is namely peaceful jihad. ${ }^{40}$ Pesantren is a place to nurture young people in religious fields. In a broader sense, they will then step up the inspiration for their homeland. There have even been alumni that went on to become leaders on the national level, who are always the actor for peace efforts. While reports of violence are linked to pesantrens are baseless. There has yet to be a legal verdict that shows pesantren as being linked to violence and terrorism.

While the national Islamic education has started efforts to adopt modern technology, the Islamic education development in Papua, however, has yet to reach that discourse. ${ }^{41}$ An important agenda of Islamic education is how to develop multicultural

\footnotetext{
${ }^{37}$ Mastuhu. 1994. Dinamika Sistem Pendidikan Pesantren: Suatu Kajian Tentang Unsur dan Nilai Sistem Pendidikan Pesantren. Jakarta: INIS

38 Wekke, Ismail Suardi. 2012. Pesantren dan Pengembangan Kurikulum Kewirausahaan: Kajian Pesantren Roudahtul Khuffadz Sorong Papua Barat. Jurnal Penelitian Sosial Keagamaan Inferensi. Vol. 6, Number 2, December: 205-226.

${ }^{39}$ Wekke, Ismail Suardi. 2011. Pendidikan Islam dan Pemberdayaan Masyarakat (Tinjauan Pendidikan Vokasional Pesantren Roudhatul Khuffadz, Sorong). Jurnal Kajian Interdisipliner Hermenia. Vol. 10, Number 1, December: 23-53.

${ }^{40}$ Lukens-Bull, R. A. 2001. Two Sides of the Same Coin: Modernity and Tradition in Islamic Education in Indonesia. Anthropology and Education Quarterly. Vol. 32, Number 3: 350-372.

${ }^{41}$ Lubis, Maimun Aqsha. Embi, Muhammad Amin. Yunus, Melor Muhammad. Wekke, Ismail Suardi. Nordin, Muhammad. 2009. "The Application of Multicultural Education and Applying ICT on Pesantren in South Sulawesi, Indonesia", WSEAS Transactions on Information Science and Applications, Vol. 6, No. 8:1401-1411.
} 
awareness. ${ }^{42}$ The existence of Muslims in Papua (and West Papua) holds a totally different meaning and position when compared to Muslims in other regions of Indonesia. Socialization and harmony with believers of other religions are seen as efforts to negotiate the Islamic identity in the middle of a stage of multiple values and culture. At the same time, there are challenges and in the process, there are extreme points within the Muslims themselves. This brings them to a dilemma that propose choosing just one of the following; to isolate oneself or to assimilate, by considering the risk of losing one's religious identity. Surely as a member of society, it would be impossible to alienate oneself from others but when involved in integrated education the cultivation of Islamic characteristics may just be neglected.

This article portrays madrasah and pesantren condition in which Islamic society reacted to multiethnic in West Papua context. It shows that pesantren from time to time often adopt and adapt to recent development and change. However, the movement failed to integrate their ideas in the real Papuan domains. Failures in expansion to both cultural and social tend to decrease of Papua student number in school. Theoretically, this school should gain attraction for Papua muslim. Fortunately, most of students attend the school is coming from different region. The realization that educational goals may be achieved through peaceful means may help to resolve daily problems in modern Papua day society. This study is relevant to Asrohah's experiences show the ability of four imperative functions of pesantren, namely high ability to adapt to the external world, wide-ranging goal achievement, integrative ability of unifying the unique aspects of pesantren as a subculture, and ability in preserving the pesantren's tradition. ${ }^{43}$

Finally, the study concludes that efforts to develop education in pesantren are not only for today. Students are always provided with learning experiences for the future. Pesantren's involvement in developing a curriculum that adapts to its environment reflects the desire to expose their students to the latest context. This preparation is done by upholding the responsibility for the future. Students will not live in the past. They live for now and the future. If the curriculum is not developed in such a way with serious and maximum efforts, surely all the learning provided will fail the students in life. The study again proves that the pesantren has made interaction with its environment a platform to maintain provision of quality education.

\section{CONCLUSION}

Muslims in demographic minority is a norm for a madrasah. From one perspective, interaction and socialization with believers of other religion is taken as encouragement to provide Islamic oriented education. On the other hand, being a part of a multicultural community ensures acceptance of others and that they are, too, a part of life. This ability is required for a Muslim in order to live among people of different religion. Since the beginning of establishment, pesantren was intended as an institution that provides capacity reinforcement for Muslim individuals.

This study shows that education is the main choice for Muslims in Sorong, West Papua for strengthening the identity of their youths. Specifically, the study on the phenomenon of al-Jihad mosque found that in its early development, the congregation built the mosque to serve as a location to perform prayers. Later on, after prayers were performed regularly there, there was a need to strengthen religious understanding,

\footnotetext{
${ }^{42}$ Raihani. 2012. "Report on Multicultural Education in Pesantren“. Compare, Vol. 42, No. 4, July: 585605.

${ }^{43}$ Asrohah, Hanun, 2011. "The Dynamics of Pesantren Responses Toward Modernity and Mechanism in Organizing Transformation”, Journal of Indonesian Islam, Vol. 05, Number 1, June: 66-90.
} 
especially for the children. It was the time for administration of the mosque decided to open a formal school that integrates the mosque as its centre. The mosque and school not only serve the interest of its congregation but in a broader sense, they serve the needs of Muslims in Sorong. Consequently, the mosque and school grew, where management and development were no longer done solely by the mosque's congregation, school's administration and students' parents but also, community organizations and committees of institutions in Sorong that supports the school's institutionalization. There is participation from parents, mulsim organization in developing together the school.

Pesantren environment in muslim minority expand to the basic need in religious practice. Therefore, muslim community started to establish learning and teaching institution to facilitate their family in reaching religious understanding. After all, the educational institutions expand to vocational and skill facilitator. They complement pesantren to skill based educational activities. Collaboration and cooperation among muslim is the pillar to support the process of development. School only is a basic institution. Beyond the educational activities, there is program to empower muslim on the pesantren's neighborhood.

Finally, the research has provided a description of how Islamic education significantly holds a special social position. So significant that even reform theory of Islamic education that occurs in other regions cannot explain the phenomenon in Sorong and West Papua Province. With that, a new point of view is presented, whereby Islamic education can indeed be established without being pioneered by a charismatic leader but by the unity of the mosque's congregation that work together to build a meaningful educational institution.

\section{REFERENCE}

Abdurrahmansyah. 2010. "Kontribusi Kurikulum Humanisme bagi Implementasi Pembelajaran Nilai di Indonesia", Jurnal Kajian Pendidikan Islam at-Tarbawi, Volume 9, Number 2, November:131-150.

Amiruddin. 2010. Muatan Lokal dan Tantangan Dunia Kerja di Madrasah Aliyah Pondok Pesantren DD Lil Banat Kota Parepare Provinsi Sulawesi Selatan, Jurnal Penelitian Agama dan Sosial Budaya, Vol. 16, No. 26, July - December:161-170.

Andaya, Barbara Watson. 2013. New Voices from Southeast Asian Women: A Review Essay. Journal of Southeast Asian Studies. Vol. 44, Number 01, February: 145-169.

Asrohah, Hanun, 2011. "The Dynamics of Pesantren Responses Toward Modernity and Mechanism in Organizing Transformation", Journal of Indonesian Islam, Vol. 05, Number 1, June: 66-90.

Baxter, Jane dan Chua, Wai Fong. 2008. The field researcher as author-writer. Qualitative Research in Accounting \& Management. Vol. 5, Number 2:101-121.

Creswell, John W. 2010. Educational Research: Planning, Conducting, and Evaluating Quantitative and Qualitative Research, Boston: Pearson.

Damopolii, Muljono. 2011. Pesantren Modern IMMIM Pencetak Muslim Modern, Jakarta: RajaGrafindo Persada.

Dicks, A. P. dan Batey, R. A. 2013. The Organic Curriculum: Development of an Undergraduate Catalytic Chemistry Course. Journal of Chemical Education. Vol. 90, Number 4, April :519-520.

Geertz, Clifford. 1973. The Interpretation of Cultures, New York: Basic Books. 
Gerrard, J; Albright, J; dan Clarke, D. J. dkk, 2013. Researching the Creation of a National Curriculum from Systems to Classrooms. Australian Journal of Education. Vol. 57, Number 1, April: 60-73.

Hamdi, S. dan Smith, B. J. 2012. "Sisters, Militias and Islam in Conflict: Qusetioning 'reconciliation' in Nahdlatul Wathan, Lombok, Indonesia", Contemporary Islam, Volume 6, Number 1, April: 29-43.

Holden, Rick dan Griggs, Vivienne. 2010. Innovative Practice in the Teaching and Learning of Human Resource Development. Journal of European Industrial Training. Vol. 34 Number 8/9:705-709.

Howell, Julia Day. 2010. Indonesia's Salafist Sufis. Modern Asian Studies. Vol. 44, Number 05, September: 1029-1051.

Izfanna, D. dan Hisyam, N. A. 2012. "A Comprehensive Approach in Developing Akhlaq: A Case Study on the Implementation of Character Education at Pondok Pesantren Darunnajah", Multicultural Education and Technology Journal, Volume 6, Number 2, June: 77-86.

Jannah, Siti Raudhatul. 2012. Kegalauan Identitas: Dilema Hubungan Muslimin dan Hindu di Bali. Jurnal Studi Keislaman Ulumuna. Vol. 16, Number 2, December: 443-464.

Lubis, Maimun Aqsha. Embi, Muhammad Amin. Yunus, Melor Muhammad. Wekke, Ismail Suardi. Nordin, Muhammad. 2009. "The Application of Multicultural Education and Applying ICT on Pesantren in South Sulawesi, Indonesia", WSEAS Transactions on Information Science and Applications, Vol. 6, No. 8:1401-1411.

Lubis, Maimun Aqsha; Wekke, Ismail S; dan Syafar, Suhartini. 2009. Pelaksanaan Teknologi Komunikasi dan Maklumat dalam Pendidikan: Implementasi di Sekolah Bestari. Saemah Rahman, Mohd Izham Mohd Hamzah, and Auzar, Reformasi Pendidikan Serantau [275-282]. Bangi: Pusat Percetakan dan Penerbitan Universiti Kebangsaan Malaysia.

Lukens-Bull, R. A. 2001. Two Sides of the Same Coin: Modernity and Tradition in Islamic Education in Indonesia. Anthropology and Education Quarterly. Vol. 32, Number 3:350- 372 .

Makbuloh, Deden. 2012. "Kultur Minoritas dalam Perspektif Pendidikan Islam”, Jurnal Studi Keislaman Analisis, Volume XII, Number 1, June:137-160.

Mangunjaya, F. Majeri. dan McKav, J. Elizabeth. 2012. "Reviving an Islamic Approach for Enviromental Conservation in Indonesia", Worldviews: Environment, Culture, Religion, Volume 16, Number 3:286-305.

Mastuhu. 1994. Dinamika Sistem Pendidikan Pesantren: Suatu Kajian Tentang Unsur dan Nilai Sistem Pendidikan Pesantren. Jakarta: INIS.

Medoff, Marshall H. 2008. The Effect of Abortion Costs on Adoption in the USA. International Journal of Social Economics. Vol. 35, Number 3:188-201.

Nilan, P. 2009. “The 'spirit of education' in Indonesian Pesantren", British Journal of Sociology of Education, Volume 30, Number 2, March: 219-232.

Nir, Adam E; dan Eyal, Ori. 2003. School-based Management and the Role Conflict of the School Superintendent. Journal of Educational Administration. Vol. 41, Number 5: 547-564.

Nurudin, "Mendesain Madrasah di Tanah Jayapura: Sebuah Kasus Kota Jayapura", Jurnal Penelitian Pendidikan Agama dan Keagamaan Edukasi, Vol. 9, No. 3, September Desember 2011, 4644 - 4671.

Permani, R. 2011. "The Presence of Religious Organisations, Religious Attendance and Eranings: Evidence from Indonesia", Journal of Socio-Economics, Volume 40, Number 3, May: 247-258. 
Putra, Nusa. 2012. Metode Penelitian Kualitatif Pendidikan. Jakarta: RajaGrafindo Persada.

Rahardjo, M. Dawam. 1995. "Dunia Pesantren dalam Peta Pembaharuan", Pesantren dan Pembaharuan, Fifth Edition, Jakarta: LP3ES.

Raihani. 2012. "Report on Multicultural Education in Pesantren".Compare, Vol. 42, No. 4, July: 585-605.

Sirry, M. 2010. "The Public Expression of Traditional Islam: The Pesantren and Civil Society in Post-Suharto Indonesia", Muslim World, Volume 100, Number 1, January: 60-77.

Smith-Hefner, Nancy J. 2008. Review of Robert Folger 'Images in Mind: Lovesickness, Spanish Sentimental Fiction and "Don Quijote." The Journal of Asian Studies. Vol. 67, Number 02, May: 747-749.

Steenbrink, Karel A. 1994. Pesantren Madrasah Sekolah, second edition, Jakarta: LP3ES.

Supardi dan Natsir, M. 2006. Analisis Kebutuhan Pengembangan Madrasah di Kota Mataram Menghadapi Akreditasi Madrasah, Jurnal Penelitian Keislaman, Vol. 3, No. 1, December: 79-98.

Susianto, H. 1993. "Studi Gaya Hidup Sebagai Upaya Mengenali Kebutuhan Anak Muda, Jurnal Psikologi dan Masyarakat, Vol. I, No. 1:55-76.

Syaukani, Imam. 2006. "Relativitas Posisi Minoritas Muslim di Tengah Mayoritas Kristen: Kasus di Kecamatan Berastagi”, Jurnal Penelitian dan Kajian Keagamaan Dialog, No. 62, Tahun XXIX, December: 55 - 69.

Tafsir, Ahmad. 2000. Ilmu Pendidikan dalam Perspektif Islam, third edition, Bandung: PT. Remaja Rosdakarya.

Wekke, Ismail Suardi. 2011. Pendidikan Islam dan Pemberdayaan Masyarakat (Tinjauan Pendidikan Vokasional Pesantren Roudhatul Khuffadz, Sorong). Jurnal Kajian Interdisipliner Hermenia. Vol. 10, Number 1, December: 23-53.

Wekke, Ismail Suardi. 2012. Pesantren dan Pengembangan Kurikulum Kewirausahaan: Kajian Pesantren Roudahtul Khuffadz Sorong Papua Barat. Jurnal Penelitian Sosial Keagamaan Inferensi. Vol. 6, Number 2, December: 205-226.

Wertheimer, M. 1945. Productive Thinking. New York: Harper \& Row.

Widjojo, Muridan S. 2007. "Nasionalisme dan Etnisitas", Firman Noor (ed), Nasionalisme, Demokratisasi dan Identitas Primordialisme, Jakarta: Puslit Politik LIPI.

Ziemek, Manfred. 1986. Pesantren Dalam Perubahan Sosial. Jakarta: P3M. 